\title{
The Importance of Simultaneous Surgical and Endoscopic Polypectomies in Peutz-Jeghers Syndrome: A Case Report
}

\section{Peutz-Jeghers Sendromunda Eș Zamanlı Cerrahi ve Endoskopik Polipektominin Önemi: Olgu Sunumu}

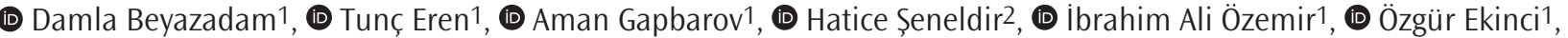 \\ (D) Orhan Alimoğlu1
}

1istanbul Medeniyet University Faculty of Medicine, Göztepe Training and Research Hospital, Department of General Surgery, İstanbul, Turkey 2istanbul Medeniyet University Faculty of Medicine, Göztepe Training and Research Hospital, Department of Pathology, Istanbul, Turkey

\begin{abstract}
Peutz-Jeghers syndrome may be presented with gastrointestinal and extra-intestinal malignancies. Herein, we report a case of Peutz-Jeghers syndrome with a malignant intestinal polyp accompanied by synchronous multiple hamartomatous gastrointestinal polyps that was treated with simultaneous surgical and endoscopic polypectomies.
\end{abstract}

Keywords: Peutz-Jeghers syndrome, polyps, adenocarcinoma, endoscopy, general surgery
öZ

Peutz-Jeghers sendromu, gastrointestinal ve ekstraintestinal maligniteler ile prezente olabilir. Yaygın hamartomatöz gastrointestinal polipler ile senkron bir malign ince bağırsak polibi olan, eş zamanlı cerrahi ve endoskopik polipektomiler ile operatif tedavi uygulanan Peutz-Jeghers sendromu olgusunu sunmayı amaçladık.

Anahtar Kelimeler: Peutz-Jeghers sendromu, polipler, adenokarsinom, endoskopi, genel cerrahi

\section{Introduction}

Peutz-Jeghers syndrome (PJS) is an autosomal dominant, hereditary syndrome, characterised by hamartomatous gastrointestinal polyps. Patients may present with hyperpigmented spots in the lips and oral mucosa, abdominal pain, haematochezia and anaemia (1). Herein, we report a case who was diagnosed with PJS, had a past history of multiple colonoscopic polypectomies and surgical enterotomic polypectomy procedures between 1996 and 2006 and was eventually re-operated on due to the ongoing formation of multiple polyps in the colon, small intestine and stomach.

\section{Case Report}

A 32-years-old man with a past history of multiple surgical and colonoscopic polypectomies, was admitted to our clinic, after he was recently diagnosed with multiple gastrointestinal polyps in various localisations during his long term follow-ups. His father and five siblings were also diagnosed with PJS. Upper gastrointestinal endoscopy of the patient revealed multiple small polypoid lesions in the stomach and duodenum. In addition to the multiple diminutive and pedunculated polyps, a large-pedunculated, lobulated, giant polyp with a size of $5 \times 5$ $\mathrm{cm}$ in the sigmoid colon was found during colonoscopy. There were also 3 diminutive polyps in the proximal transverse colon. Abdominal magnetic resonance imaging (MRI) revealed focal dilations accompanied by diffuse hypo-intense areas filling the small intestinal lumen and suspected contrast enhancements within these mass lesions. Additionally, MRI revealed a contrast enhanced irregular mass lesion, filling approximately $50 \%$ of the sigmoid colon lumen that extended along a segment of 6.5 $\mathrm{cm}$. After obtaining a written informed consent from the patient, he was admitted to the general surgery department and underwent surgery. The surgical abdominal exploration revealed multiple, intraluminal palpable small intestinal polypoid lesions starting from the proximal jejunum and continuing approximately $150 \mathrm{~cm}$ distally from the ligament of Treitz. On the other hand, since the colonic polyps were found to be soft in texture on palpation, it was decided to perform an intraoperative colonoscopy to determine the exact location of the large sigmoid polyp, which showed hundreds of millimetric polyps throughout the colon, in addition to the giant pedunculated 6-cm-sized polyp in the sigmoid colon (Figure 1). Intraoperative enteroscopy performed via an
Presented in: This case was presented at the $17^{\text {th }}$ Turkish Colon \& Rectal Surgery Congress in Antalya, Turkey between April $9^{\text {th }}-13^{\text {th }}, 2019$.

Address for Correspondence/Yazıșma Adresi: Tunç Eren MD, Assoc. Prof., İstanbul Medeniyet University Faculty of Medicine, Göztepe Training and Research Hospital, Department of General Surgery, İstanbul, Turkey

Phone: +90 5322447494 E-mail: drtunceren@gmail.com ORCID ID: orcid.org/0000-0001-7651-4321

Cite this article as/Atıf: : Beyazadam D, Eren T, Gapbarov A, Seneldir H, Özemir İA, Ekinci Ö, Alimoğlu O.

The Importance of Simultaneous Surgical and Endoscopic Polypectomies in Peutz-Jeghers Syndrome: A Case Report. İstanbul Med J 2020; 21(5): 404-7.

(c) Copyright 2020 by the University of Health Sciences Turkey, Istanbul Training and Research Hospital/istanbul Medical Journal published by Galenos Publishing House.

(C) Telif Hakkı 2020 Sağılk Bilimleri Üniversitesi Istanbul Eğitim ve Araștırma Hastanesi/istanbul Tıp Dergisi, Galenos Yayınevi tarafından basılmıștır.
Received/Geliş Tarihi: 22.06.2020 Accepted/Kabul Tarihi: 04.08.2020 
enterotomy $70 \mathrm{~cm}$ distal to the ligament of Treitz showed hundreds of subcentimetric polyps. Multiple surgical and endoscopic polypectomies were performed via enterotomies created at 70, 100 and $120 \mathrm{~cm}$ distally from the ligament of Treitz (Figure 2). Segmental colon resection with clear surgical margins and end-to-end anastomosis were performed due to the giant polyp in the sigmoid colon. The patient was discharged on the $8^{\text {th }}$ postoperative day without any postoperative complications. Histopathological examination revealed a total number of 52 polyps. There was a pedunculated hamartamatous intestinal polyp with diameters of $3.5 \times 2 \times 1.7 \mathrm{~cm}$, located in a jejunal segment $90 \mathrm{~cm}$ distally

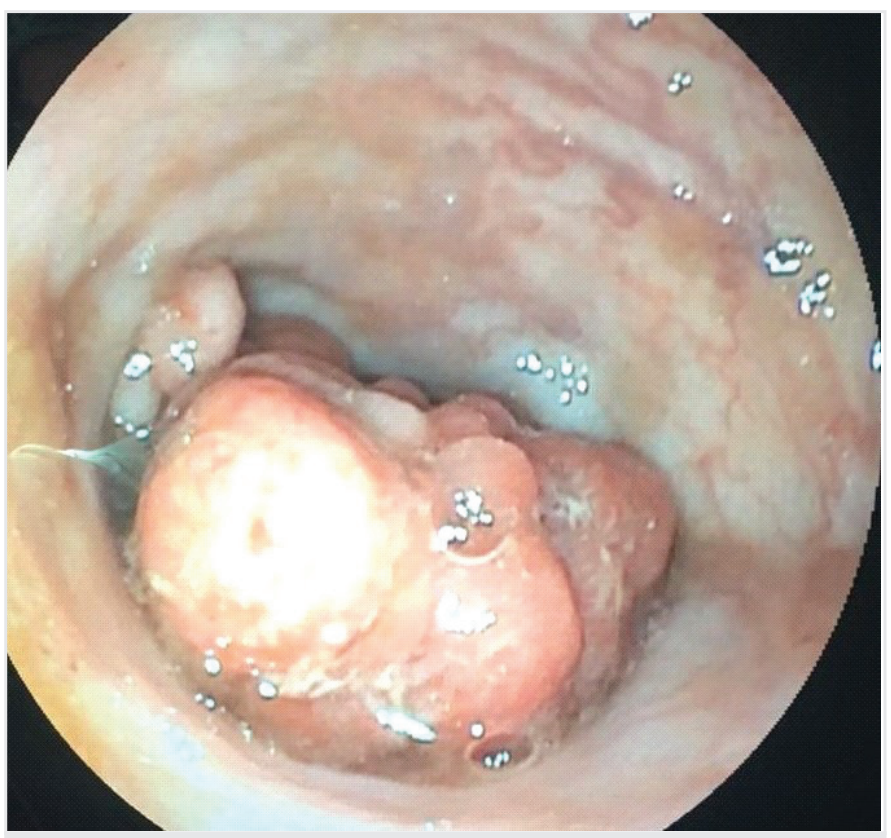

Figure 1. Colonoscopic image of the pedunculated 6-cm-sized giant polyp in the sigmoid colon

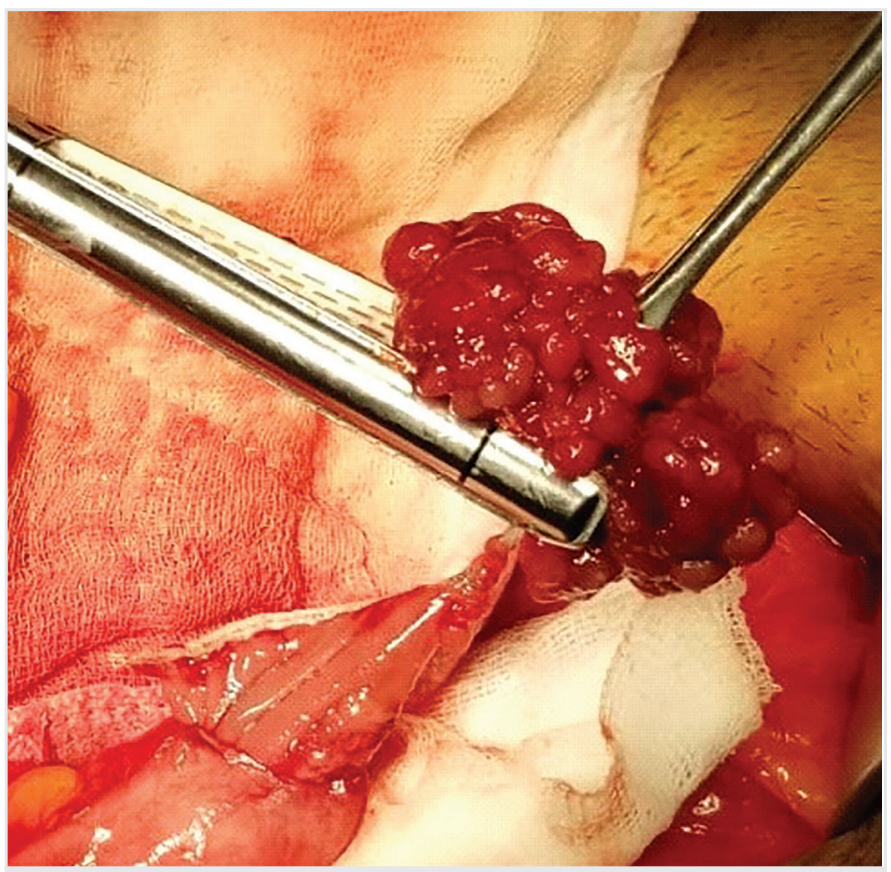

Figure 2. Mucosal polyp excision via enterotomy to the ligament of Treitz, the histopathology of which was found to be a well differentiated intramucosal adenocarcinoma. The carcinoma had a size of $0.2 \mathrm{~cm}$ and its distance to the surgical margin was approximately $1 \mathrm{~cm}$. The stage of this lesion was defined as PTis NO M0 according to the American Joint Committee on Cancer tumor-node-metastasis staging system (Figure 3). Additionally, four of the polyps located at the jejunal segments $0,10,60$ and $70 \mathrm{~cm}$ distally to the ligament of Treitz were found histopathologically to be focally low-graded hamartomatous polyps with adenomatous changes. All of the other polypectomy specimens were defined as hamartomatous polyps. Histopathological review of the segmental sigmoid colon resection material revealed a 6-cm-sized lobulated giant polypoid lesion formed by a collection of multiple hamartomatous polyps.

\section{Discussion}

PJS is an autosomal dominant inherited disorder with an estimated incidence of 1:50,000-1:200,000, characterised by mucocutaneous melanin pigmentation and gastrointestinal hamartomatous polyps (1). STK11/LKB1 gene mutation has been proven as an etiological factor of PJS and $70 \%$ of PJS patients have a positive family history $(1,2)$. Most PJS polyps are of the hamartomatous type, and they are mostly reported to be localised in the jejunum, colon, rectum, duodenum and stomach, respectively; nonetheless, they can be present in the entire gastrointestinal tract (3). We report a case that presented with multiple gastric, duodenal, jejunal and colonic hamartomatous polyps.

PJS is a disorder with an increased susceptibility for tumours, and it is also a predisposing factor for gastrointestinal and non-gastrointestinal malignancies (4). Tumour incidence in PJS patients is 15 times greater than in the general population, whereas malignancy incidence is approximately $20 \%$ (3). The lifetime risk of developing gastrointestinal malignancies among PJS patients is estimated as 39\% for colon cancer, $36 \%$ for pancreatic cancer, 29\% for gastric cancer, 19\% for intestinal cancer and $0.5 \%$ for oesophageal cancer (4). Additionally, for nongastrointestinal malignancies, estimated risks are determined as $54 \%$ for breast cancer, $21 \%$ for ovarian cancer, $15 \%$ for lung cancer and 9\% for endometrial cancer (5). Studies have shown that the cancer

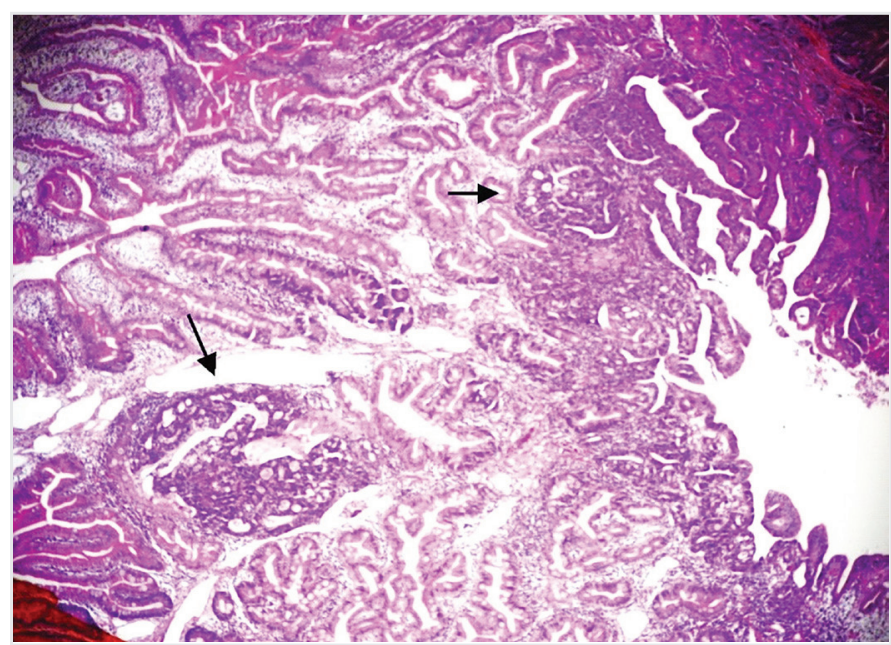

Figure 3. Intramucosal adenocarcinoma developed in a hamartomatous polyp $(\mathrm{H} \& \mathrm{E} \times 40)$ 
predisposition is not only due to the mutation in the STK11 gene, but is also associated with the hamartoma-adenoma-carcinoma sequence or directly with the hamartoma-carcinoma transition (6). In the presented case, a total number of 52 intestinal and colonic polyps were removed, and one of the intestinal polyps was detected to harbour a focus of intramucosal adenocarcinoma.

PJS patients clinically present with symptoms such as intestinal obstruction (43\%), abdominal pain (23\%), gastrointestinal system haemorrhage (14\%), hyperpigmented skin (13\%) and the presence of anal polyps (7\%) (5). Acute mechanical intestinal obstruction, which can be caused by various conditions such as invagination and malignancy, is one of the most common complications of PJS (6). Invagination is a severe complication that can occur in $47 \%$ of younger patients $(1,5)$. Family members of PJS patients also have a high incidence of the syndrome and therefore, screening protocols have been developed for the first degree relatives of PJS patients who are considered to be in the high risk group (1). These individuals must have annual examinations beginning at birth for the hyperpigmented lesions. Due to the high risk of invagination-related obstruction seen in the early ages, asymptomatic children at risk may be advised to take a test at the age of 8 for the mutation in the STK11 gene. The case presented herein had a family history of PJS, as well as a history of previous surgical and endoscopic polypectomies. Therefore, he was being followed-up endoscopically and an elective surgery was performed due to the recent findings of multiple polypoid lesions detected during his long term follow-ups.

Imaging methods such as magnetic resonance enterography and barium series may be recommended for adults. Upper gastrointestinal tract and intestinal endoscopy as well as colonoscopy are also recommended by various authors at the ages of 12, 18 and 24 years, respectively (7).

One of the leading PJS-related cancers is breast cancer (32\%-54\%). The incidence rate of PJS-related breast cancer is similar to that of the BRCA 1-2 gene-related breast and ovarian cancers (4). Hence, the same breast cancer screening recommendations are used for patients with PJS and BRCA 1-2 mutations (1). Breast examination on a monthly basis starting from the age of 18, annual MRIs and/or ultrasonographies since the age of 25 and regular mammographic screenings are recommended (7).

Colorectal cancers are the second most common cancers associated with PJS. Colonoscopic examinations starting from the age of 18 or 5-10 years before the earliest occurrence of cancer in the family members, and repeating the colonoscopy within 2-3 years are recommended (1). Since a giant sigmoid polyp was detected in the presented case, a segmental sigmoid resection was performed because of the risk of colon cancer that could be associated with PJS. However, the histopathological examination of this lesion revealed that it was a collection of multiple hamartomatous polyps that did not harbour any malignant foci.

Pancreatic cancer is the third most common malignancy and often starts at the ages of 25-30; annual screening methods such as endoscopic ultrasonography, MRI and magnetic resonance cholangiopancreatography may be planned (1).

The incidence of gastric cancer is approximately 29\%, whereas that of intestinal cancer is $13 \%$. Therefore, upper gastrointestinal endoscopic surveillance with an interval of 2-3 years, starting from the age of 18 is recommended. Capsule endoscopy may be used as well $(8,9)$. For gastric and colonic polyps larger than $1 \mathrm{~cm}$, polypectomy via endoscopy is recommended (9). Surgical excision is recommended for asymptomatic polyps larger than $1.5 \mathrm{~cm}$ or symptomatic/fast growing polyps (9). Upper gastrointestinal endoscopy of our patient revealed multiple small polypoid lesions in the stomach and duodenum, and it was decided to be reserved for continued endoscopic surveillance, whereas it was decided that the polyps detected throughout the small intestinal and colonic lumen be removed surgically.

All the palpable intraluminal lesions must be resected in case of emergency and/or elective laparotomies, on account of the fact that intestinal lesions may be overlooked during endoscopic surveillance, and because there is a risk of malignancy related to PJS (6). In order to clear the entire intestinal system of polyps, intraoperative endoscopies, and in cases of larger polyps, enterotomies are recommended $(2,6,10)$. This "clean sweep" approach is identified as a solution that minimises the requirement for recurrent small bowel surgeries (10). In this context, we performed multiple intestinal and colonic surgical polypectomies in our case with the use of intraoperative enteroscopy and colonoscopy, in addition to a segmental colon resection with the aim of cleaning all the polyps that could be localised during surgery.

Since hamartomas in patients with PJS possess a risk of malignancy, these cases must be strictly followed-up, thus for newly developed polyps, endoscopic polypectomies must be performed, and in case of necessity for a surgical intervention, all facilities including intraoperative endoscopy must be used in order to remove the polyps completely.

\section{Ethics}

Informed Consent: Written informed consent was obtained from the patient for being included in the case report.

Peer-review: Externally peer-reviewed.

Authorship Contributions: Surgical and Medical Practices- T.E., H.Ş., A.G., I.A.Ö., Ö.E., O.A. ; Concept- D.B., T.E., A.G., Ö.E., O.A. ; Design- D.B., T.E., A.G., Ö.E., O.A. ; Data Collection or Processing- D.B., T.E., A.G., H.Ş., I.A.Ö. ; Analysis or Interpretation- T.E., A.G., H.S,., I.A.Ö., Ö.E., O.A. ; Literature Search- D.B., T.E., A.G., I.A.Ö. ; Writing- D.B., T.E., A.G.

Conflict of Interest: No conflict of interest was declared by the authors.

Financial Disclosure: The authors declared that this study received no financial support

\section{References}

1. Giardiello FM, Trimbath JD. Peutz-Jeghers syndrome and management recommendations. Clin Gastroenterol Hepatol 2006; 4: 408-15.

2. Alimoğlu 0, Sahin M, Cefle K, Celik O, Eryilmaz R, Palandüz S. Peutz-Jeghers syndrome: Report of 6 cases in a family and management of polyps with intraoperative endoscopy. Turk J Gastroenterol 2004; 15: 164-8.

3. Sharma M, Singh R, Grover AS. Peutz-jeghers syndrome with synchronous adenocarcinoma arising from ileal polyps. Indian J Surg 2015; 77(Suppl 1): $100-2$.

4. Giardiello FM, Brensinger JD, Tersmette AC, Goodman SN, Petersen GM Booker SV. Very high risk of cancer on familial Peutz-Jeghers syndrome. Gastroenterology 2000; 119: 1447-53. 
5. Wangler MF, Chavan R, Hicks MJ, Nuchtern JG, Hegde M, Plon SE, et al. Unusually early presentation of small-bowel adenocarcinoma in a patient with Peutz-Jeghers syndrome. J Pediatr Hematol Oncol 2013; 35: 323-8.

6. Eren T, Bayraktar B, Celik Y, Boluk S, Adali G. Acute malignant intestinal obstruction accompanied by synchronous multifocal intestinal cancer in Peutz-Jeghers syndrome: report of a case. Surg Today 2012; 42: 1125-9.

7. Beggs AD, Latchford AR, Vasen HF, Moslein G, Alonso A, Aretz S, et al. Peutz-Jeghers syndrome: a systematic review and recommendations for management. Gut 2010; 59: 975-86.

8. Hinds R, Philp C, Hyer W, Fell JM. Complications of childhood Peutz-Jeghers syndrome: implications for pediatric screening. J Pediatr Gastroenterol Nutr 2004; 39: 219-20.
9. Giardiello FM. Gastrointestinal polyposis syndromes and hereditary nonpolyposis colorectal cancer. In: Rustgi AK (ed). Gastrointestinal cancers: biology, diagnosis, and therapy. Philadelphia: Lippincott-Raven Publishers; 1995.p.370-1.

10. Oncel M, Remzi FH, Church JM, Connor JT, Fazio VW. Benefits of 'clean sweep' in Peutz-Jeghers patients. Colorectal Dis 2004; 6: 332-5. 